

Volume 6 Nomor 1, April 2019: 1-11

\section{Dream Interpretation of an Infant and Feminine Monstrosity in Among the Sleep}

Karen Winardi \& Lucia Lusi Ani Handayani

English Study Program, Faculty of Humanities

Universitas Indonesia

Kampus UI Depok, Jln. Margonda Raya, Depok Jawa Barat - 16424

E-mail: karen.winardi97@gmail.com \& lucia.lusi@ui.ac.id

\begin{abstract}
ABSTRAK
Tafsir Mimpi Tokoh Utama Bayi dan Elemen Horor Feminin dalam Game Among the Sleep. Game Among The Sleep (2014) yang menyoroti perjalanan seorang bayi mencari kenangan-kenangan bersama ibunya ini memiliki ulasan beragam dari segi kesederhanaan teka-tekinya dan acaknya peletakkan simbolisme. Akan tetapi, gaya penceritaan dan aspek visual untuk membangun momentum cerita hingga mencapai resolusi penuh emosi dari game ini masih menuai pujian. Berkebalikan dari anggapan umum bahwa bayi sama sekali tidak dapat memahami kejadian di lingkungan sekitar mereka, tokoh utama bayi dalam game Among The Sleep mampu melakukan hal tersebut dengan bantuan mimpi dan fantasi.Menurut Freud, kedua hal tersebut akanmempengaruhi kepribadianbayi saat bertumbuh besar dari alam bawah sadar. Penelitian ini bertujuan memahami makna dari simbolisme mimpi tokoh utama game dengan teori tafsir mimpi Freud. Hasil dari penelitian ini menunjukkan bahwa elemen-elemen mimpi yang muncul bertujuan untuk memenuhi keinginan terpendam sang tokoh utama, dan hal tersebut merupakan wujud dari kemampuan kognitif bayi tersebut untuk bertahan di lingkungannya. Selain itu, dengan konsep abjeksi dan histeria, diketahui bahwa sosok ibu dari kenangan sang tokoh utama seringkali dipenuhi oleh elemen horor feminin demi memenuhi hasratnya memiliki sebuah penis dengan berupaya mengkastrasi anaknya. Seperti video game pada umumnya, elemen intrinsik penceritaan Among The Sleep membawa pesan untuk meyakinkan audiensnya mereka mampu melalui trauma yang mereka alami.
\end{abstract}

Kata kunci: tafsir mimpi; horor feminin; Among The Sleep

\begin{abstract}
Among The Sleep (2014) follows an infant in his quest to search for memories of his mother. The game receives mixed opinions regarding its overly simple puzzles and confusing juxtaposition of the dream symbols; nevertheless, it is still praised for its storytelling and visuals used to build the momentum leading up to the resolution invoking strong emotions in players. Contrary to a popular belief that infants are incapable of understanding the events around them, in this game the infant can process his surroundings with the help of dreams and fantasies. In Freudian perspective, they will unconsciously affect an infant's personality when growing up. This research aims to understand the infant's dreams using Freud's interpretation of dreams. The findings show that the dream elements are the wish-fulfilment part of the infant's cognitive ability to cope with his surroundings. Moreover, using the concepts of abjection and hysteria, it is revealed that memories of his mother are often filled with feminine monstrosity to satiate her desire for having a penis by attempting to castrate him. Similar to many other video games, Among The Sleep carries a message through its storytelling elements, and it is to encourage the audience to tackle their own trauma.
\end{abstract}

Keywords: dream interpretation; video games; abjection; Among the Sleep 


\section{Introduction}

In a 2016 interview article with the developers of Krillbite Studio written by Black of halloweenlove. com, the developers wrote, "We had, and have, a wish to tell stories that are close to our heart, but not directly about ourselves [...]" when asked about the motivation of writing the plot of one of their games. Storytelling media such as video games contains verbal and visual clues to let the audience know how the characters think, what they want, and how they act. Sometimes, they will feature such elements in the character's dream, and this can apply to infant characters as well. When infants are the center of a story, the focus will also include how they are raised by their parents, as well as how they impact the child's development.

One of the video games which is focused on an infant as its main character is the first-person survival horror game Among The Sleep, which was developed by a Norwegian game studio named Krillbite Studio in 2011. The game's early alpha build was released in 2013, and in 2014, the full final build followed suit. Set in the modern era, it tells the story of a baby having to find his mother who went missing suddenly after she puts him to sleep. Most of the gameplay takes place in the dream world shaped by the main character's mind on how he sees the real world around him. During the course of the game, the player has to guide the main character to solve puzzles, hide from the monster lurking around the dream world, and find mementos of the mother in random places of the dream realm in order to complete the story.

Unlike most horror video games, since the main character is an infant, the player must switch from two types of locomotion system: crawling and walking to traverse through the obstacles in the dream world. Instead of a weapon or any other items that can be used to hit objects, the infant is accompanied by a talking teddy bear which sometimes gives hints to puzzles and can be hugged by pressing a certain button to act as a light source.

In terms of reception, Among The Sleep mostly receives mixed scores from video game reviewers. The game is criticized for the overly simple puzzle, the gameplay's smoothness, and the lack of meaningfulness in terms of the symbolisms' juxtaposition, as written in a video game review by Carolyn Petit (2014) published in Gamespotwebsite and Dave Meikleham (2014) in Games Radar. However, it receives praise for its storytelling and ambience from many reviewers, such as Andrew Webster (2013) of The Verge and Caitlin Cookie (2015) of Games Radar website.

While the story concept of delving into the mind of an infant is quite novel, it proves to be vital in understanding the impact of parenting on their development. Nevertheless, portrayals of infants' way to perceive the world around them in media and researches revolving around such topic are few as the concept itself is rarely explored. In other words, there are no scholarly articles which discuss about this game as well. Putri (2014) explains the symbolic meaning of a child main character's dreams in her study, yet she neglects to mention how the character development from the dreams affects other people around her and the problematic portrayal of the parents' personality and rearing style in the novel.

Many scholarly authors have discussed about how dreams work and what they are for in psychoanalysis realm. Most of the articles cited in this paper agree that dreams are a mechanism of wish-fulfillment from reality, albeit with slight differences. Share (1994) states that dreams are the metaphorical expression of one's understanding regarding an event in their real life. Freud (2010) agrees with such definition regarding dreams to an extent, but he adds that dreams are also "a way to fulfill one's repressed wish in reality.” (p. 3) Stern (1991)'s understanding on what dreams are also concedes with the prior definitions, but he focuses specifically on what they mean for infants, which is "the result of how [they] process the surroundings around them without any intervention from the defense mechanisms." (p. 10)

Additionally, according to psychoanalytic child development model, infancy-from 0 weeks old to 1 year old - is one of the most important stages of life as unconscious memories are developed through learning how to respond to external stimuli, fulfill their id's needs, and cope with delayed gratification during that period (Lichtenberg, 1998, p. 43- 
48). Aside from unconscious memory, fantasy is also an important aspect during this age range as Lichtenberg (1998) discovered that infants can utilize their imagination to make sense of their environment, together with their developing five senses, and it is one of the milestones they must achieve to develop healthily (p. 105). Unconscious memories and imagination show that babies indeed can process the events surrounding them which in a way, will influence what kind of person they will be when they grow older, even though they cannot verbalize their thoughts (Putri, 2014). This is because infants' consciousness has been predesigned to develop in such way ever since they were in the womb. (Stern, 1991)

This paper intends to examine the contents of the video game Among The Sleep. The data that will be utilized for the research is the visual aspect of the game's stages taking place in the main character's dream, as well as the intrinsic elements of the game such as plot and characterization. In addition, the collected data will be analyzed using Freudian psychoanalysis theoretical framework, specifically on dream interpretation and attachment to mother figure, and Kristeva's theory of abjection. In Freud's (1905) theory of maternal attachment, he stated that a mother is her son's first "love object", and the stages of development experienced by the child is highly related to growing out of his sexual obsession towards his mother-his id, which sometimes manifests in the form of dreams - to understand human relations better and compromise with the superego (p. 1). Freud (2010) also discovered that memories formed during the infancy period are stored away in the unconscious mind, which renders them inaccessible for most of the time but while dreaming in sleep (p. 4-5). However, they still play a vital role of influencing one's personality, mindset, and even what is deemed to be traumatizing for oneself (Freud, 1922).

On the other hand, abjection according to Kristeva (1982) is a group of taboo elements which incites horror or disgust because they disrupt the order of society and one's identity, so they are rejected (p. 3-4). One of the examples of such elements, especially in the horror genre, is a corpse because it reminds humans of their mortality. Other instances include pus, blood, feces, and many more for they are the accumulation of dirty elements-toxin and bacteria, to name a few-discarded by the body.

The following sections of the paper shall analyze how the infant's dream elements symbolize his longing towards his mother and how the portrayal of the mother in the dream represents abjection. All of these elements disprove the common belief that babies do not understand the events in their surroundings because what they hear and see will be imprinted in the unconscious mind. It is worth noting that whatever is stored in infants' unconscious mind affects how they will develop as they get older in different ways, which is why special care must be taken by families to ensure that the surrounding environment can accommodate and encourage their growth starting from the moment their cognitive ability develops.

\section{Longing for Mother in Memories}

The overall plot of the game follows the development of the infant's understanding of his mother as his sole caregiver as detailed in his dreams and the events of the game. During the prelude of the game, the camera shows a hazy scene as its main background, which is then eventually revealed to be a mere reflection of the glass cup held by the baby when shone under the dining room's source of light. It alludes to the dreamlike nature of the game, which serves as the basis of the baby's attempt to relive the fantasy of being with mother through good memories of her. The first half of the game focuses more on the oral phase of the psychosexual development according to Freud, which is the period when infants' receptor of pleasure is concentrated the most in the mouth or oral aperture (1920, p. 2-6). This means that the infant will either put everything he can reach into his mouth to satisfy his desire out of his own will or being fed under the caretaker's control, such as in the case of the game when the mother is feeding the baby a slice of cake to his mouth.

After the prelude, the game is then divided into five dream worlds which can be considered as the 'stages.' The player enters the dream world after encountering a silhouette image of the infant's 
memory with the mother, which is interacting with a music box together with her. The very first dream world encountered by the player is a wooden playhouse, which also acts like the checkpoint of the game, standing in the middle of a nowhere cliff. When the player enters the playhouse, one is greeted by numerous furniture resembling those of toy housewares found in doll houses. At the corner, if one looks hard enough, a piece of paper containing a scribble of hand drawing of the playhouse's exterior and overhead map of the interior which seem as if they are made by a child.

In the center of the room, one can find a circular door sealed shut, with some tubes on its side connected to it (figure 1). The tube and the door play an important part later in the game, which is to store the memories and serve as a mechanism of unlocking the door to progress to the next stage; hence its function as the game's checkpoint. The interior of the door and how the baby then enters it is also interesting to note. Every time the door is unlocked to progress to the next stage, it reveals a small pipeline inside. When the baby enters the tunnel to enter another dream world, he slides down before the scene fades out to the next stage.

In a way, the door and the pipeline allude the function of a woman's womb (figure 2). The small tunnel alludes to the function of the vagina, whereas the tunnel and the pipeline behind the door alludes to the function of cervix. The end of the pipeline seems to allude to the function of uterus, which according to Freud (1927), is a mysterious vastness of dark continent (p. 10).

In one of his works, Beyond the Pleasure Principle, Freud (1922) stated that the fundamental

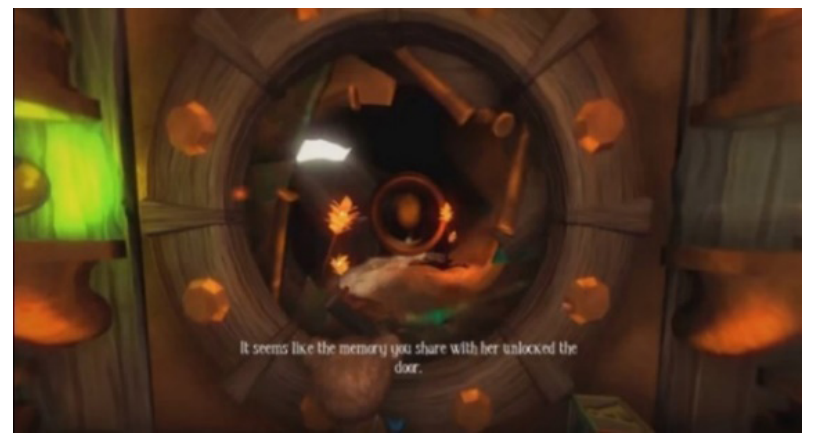

Figure 1. The door and tunnel leading up to the next stages. (Source: author's personal screenshot of the game. Time taken: July $12^{\text {th }}, 2018$ ) way to feel primal pleasure is to go back to the mother's womb to relive utmost connection with the mother (p. 15). While the baby seems to enter the pathway on his own every time he goes into another stage, he is actually not alone. Each time he passes through the checkpoint, he is accompanied with the happy memory of the mother that he has obtained previously, and his goal of traveling from one dream world to another is to obtain more happy memories with his mother. To put it short, the door and the pipeline slide are just some of the baby's mechanisms to derive pleasure from the mother aside from the visual dreams.

The first dream encountered symbolizes the infant's desire to play together with the mother. According to Stern (1991), playing together is one of many ways that infants can connect with their primary caretaker. Through that, they learn how to interact with other people, understand others' reaction, as well as their sense of self (p. 30). It can be determined that play is indeed an important factor in child development, especially for infants. In addition, the second dream which features a playground as its background and another memory of playing peek-a-boo with the mother also bears the same symbolism as the first memory of interacting with a music box together with mother, which was obtained during the first stage. Both of these memories of playing together feature no sound and only a visual of the mother's silhouette in white. However, the memory of peek-a-boo also implies the baby's fear of losing the mother.

Freud (1922) stated that peek-a-boo is a game that introduces the concept of 'people-permanence', in which the primary caretaker can also be away from the baby (p. 45). The game nurtures the

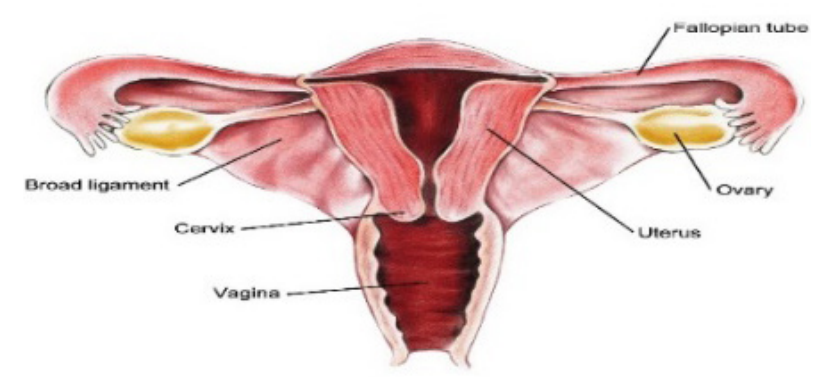

Figure 2. The anatomy of a woman's womb. (Source: https:/www.slhd.nsw.gov.au/services/sgog/Ovary.html Time taken: July $12^{\text {th }}, 2018$ ) 
feeling of worry and fear due to not being able to see the caretaker's face clearly, but at the same time induces a sense of surprise as well from learning that the caretaker is still present with the baby. If tied to the plot of the game, the memory of playing peek-a-boo mirrors the baby's separation anxiety after learning that the mother has gone missing out of a sudden, and he must find her back by collecting memories of her.

The third dream features a large castle that is filled with several framed illustrations. It has a big tree at the dead center which acts as a podium to contain a space for jigsaw puzzle (figure 3 ). Trees, in a Freudian point of view, often symbolize the penis. The fact that the tree seems to have been cut in half most likely alludes to castration, which will be explained more in-depth as the story develops. What is interesting about this castle is the fact that it is featured as the background of the bedtime story often read to the infant by the mother, as shown in the memory obtained after reaching the end of this stage. The illustrations decorating the wall of the castles are the scenes of said story. These elements mirror the desire to live out a fantasy as constructed by the mother who acts as the infant's main object of attachment to feel secure. Listening to a bedtime story is one of many ways to strengthen attachment to mother as a first love object and learning about other people as well at the same time.

According to Freud (1922), a child's attachment with the mother is formed when his needs such as hunger, thirst, and physical affection are fulfilled (p. 25). The last part of the baby's basic needs is fulfilled when the mother's habit of kissing and stroking his head before tucking him to bed. In the case of listening to a bedtime story read by the mother, the desire for fantasizing about something else based on reality is fulfilled together with the desire for knowing that the mother is present with her voice soothing the baby to sleep. In turn, the infant responds by listening to the mother and looking at her intently as she reads the story. This coincides with Lichtenberg's (1998) statement in which infants are capable of reenacting pleasant memories in their mind as long as the mother's action and the sensation felt by the infant are reinforced on constant basis (p. 66-68). Henceforth, the castle in the third stage is the form of the main character's attempt to establish an emotional connection with the mother from listening to the story associated with the mother repeatedly.

The fourth dream features a warehouse as its setting. The warehouse has numerous doors in various colors, and the floor is cluttered with papers thrown here and there. Compared to the first two dreams, the atmosphere here is dominated with dark colors from minimal lighting. Should the player open the door, the player will either find another path leading to the memory at the end of the dream or a trap leading to the lurking monster. The stage's numerous doors represent the baby as still being unable to let go of his happy memories with his mother. This emotion is evident in the form of the silhouette memory obtained at this stage, which is being held up high by the mother. This is the only instance when the mother is seen standing up, positioning herself to look far taller than the baby. Lacan (1953) stated that during an infant's mirror stage or early period of attachment to mother, he is still unable to separate himself from his mother or understand that his mother and himself are two different entities (p. 25). In other words, he still feels that he is connected to his mother as one individual. The fact that the memory in this warehouse stage is in a white silhouette that makes the mother and the baby connected to each other echoes with Lacan's theory.

Freud (1922) theorizes that the mother's bosom is a major source of the baby's obsession and pleasure (p. 17). While taking in the mother's warmth from her bosom, the baby can also feel the thrill of being up high above the ground. According to Lichtenberg (1998), this also serves as another

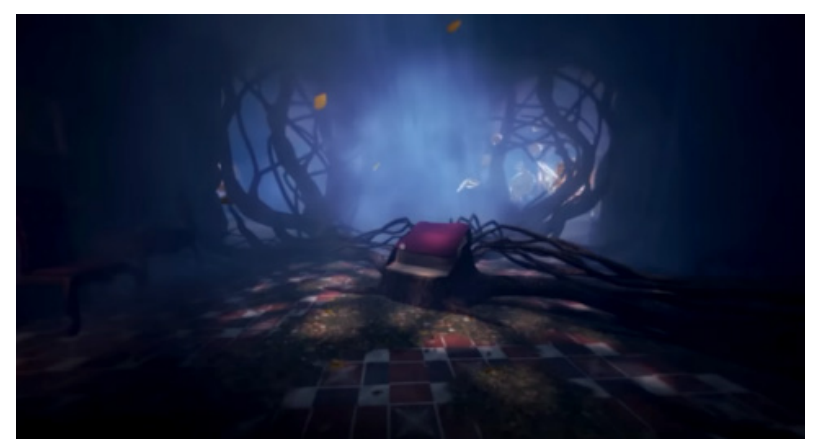

Figure 3. The big tree, cut in half, at the center of the castle. (Source: author's personal screenshot.

Time taken: July $12^{\text {th }}, 2018$ ) 
bonding mechanism for both the infant and the mother (p. 68). The thrill experienced by the baby elicits the same response in the mother through an emotional link in their brains, and this strengthens their psychological connection. Through Freud's (1905)'s findings, this is the same as fulfilling both parties' desire; the baby can come closer with the mother's bosom, while the mother's view of her baby as her possession and extension to her feminine instincts is strengthened (p. 20).

The final dream is set in an empty dark gray room. The baby can only move straight in this place, and if one looks around with the camera, there is nothing but black vastness. After taking a few steps, a light is shone, showing the mother standing in the dead center of the room with her back facing the baby. Should the baby try to approach her, the light is shut off only to be turned on again to show the mother at very same position, albeit getting further and further as the game progresses. Throughout the dream, the mother keeps repeating the words, "Not now", "Please go somewhere else, Mommy had a very rough day", and "I'll just ... one more." As her voice and the baby's vision become more distorted, she eventually turns into the very same monster that the player had encountered in the previous stages, and her monstrous form's face is shown close-up hovering above the baby. Finally, the dream ends with her saying, "He will not take you away from me" with her positioned taller in front of the baby while facing him, but her face is reduced into black silhouette from the setting's lighting. The camera then fades out into a white screen.

This stage symbolizes the moment to face the truth of the mother's abusive side for the baby. Here, the mother is portrayed as an abusive and distant person as opposed to her depiction in the memories collected by the baby as well as in the prelude. Freud (2010) stated that nightmares that occur frequently are also a form of wish-fulfillment (p. 55), but instead of invoking the 'Eros' side symbolizing love for life and happiness like the happy memories with mother found at the previous stages, the wish resonates with the 'Thanatos' side seeking for death or destruction to oneself ( $p$. 30). This dream represents the self-crippling, but non-lethal, 'Thanatos' aspect of the infant's wish to go after his mother and stay with her as she is his only caregiver, although he is sometimes neglected and even abused when the mother resorts to alcohol. This is evident in the moment when the mother would often shove the baby away when he approaches her while she is under the intoxication of alcohol or smash a bottle in the baby's vicinity as shown from the sound of glass breaking and the glass shards strewn around the floor when she appears in the dark gray room.

Lyons-Ruth, K. Dutra, L. Schuder, M. R. Bianchi (2006) wrote that infants who are raised in abusive household are trapped in a repeating cycle. When infants' request for their needs to be fulfilled is met with the primary caregiver's negative reaction, their cry intensifies even more to invoke a sense of urgency in the caregiver (p. 5) and in turn intensifies the mother-infant attachment (Ainsworth, 1979, p. 936). However, in most of the observed subjects, the caretaker would always turn down their infants' cry for their needs, thus distancing themselves further from the infant, which in turn provokes the infant to cry even more (Lyons-Ruth, K. Dutra, L. Schuder, M. R. Bianchi, 2006). This creates a distortion in their attachment style, possibly leading to dissociation that strains the infant's development of social and empathy skills (Lyons-Ruth, K. Dutra, L. Schuder, M. R. Bianchi, 2006, p. 6-7). According to Lacan (1953), the infant's repeated exposure to negative stimuli from the caretaker is how 'learned helplessness' happens (p. 10). In other words, the baby tries to cope with it by accepting the fact that even though the caretaker neglects or abuses him to the extent it may impact his social development in the running years, he knows he cannot escape because the caretaker is the only person by his side to fulfill his needs for food and affection.

While the puzzles provided in each stage provide no symbolism to the aspect of longing towards the mother in the infant himself and only served to lengthen the game's playthrough time, the game makes it up in how it narrates the story. Instead of numerous dialogues between the baby and his mother or the teddy bear, game highly relies on the eerie atmosphere and subtle visual clues, 
such as the overall dark color palette dominating the whole dream world, the picture of the third stage's background in the storybook read to the baby, and scribble of hand drawings made by the baby which are found scattered on the ground, to deliver the story and whatever is going on in the infant's mind as he seeks his mother.

Throughout the process of trying to find out where the mother has gone to while playing the game, the game renders the player tense on their seat, only to be utterly shocked upon facing the dream world's lurking monster and learning what role it represents in the infant's mind as written by Andrew Verge of The Verge (2013) and Caitlin Cookie of Games Radar (2015) in their respective game review articles.

\section{Hysteria and Abjection in the Portrayal of the Mother}

From the muffled arguing sounds heard at the background of the prelude after she left the baby to open the door, it is possible that the mother is having a dispute with her husband regarding the husband's visitation rights or his attempt to win the rights to child custody. If we see this event from Freudian (1927) perspective, after a woman bears a child, she thinks that she has resolved her ongoing penis envy (p. 10). However, in reality, this does not resolve the most fundamental sense of inferiority because the woman never has a physical real penis like men do. That is why when a mother loses a child from watching him growing up, they will experience hysteria.

If put into the context of this game, when the mother is about to lose her son, the symptoms of hysteria grow stronger alongside the game. The fact that the plot of the game grows darker together with the hysteria intensifying is alluded by the process of entering the cervix-like pipeline (see figure 1 $\& 2$ ) leading up to the next dreams bridged by a dark vastness that is the womb. Freud stated that a woman's womb is akin to a dark and mysterious continent with nothing known surrounding it, which may serve as a foreshadowing to the dark aspect of the mother's personality that the infant will discover at the end.
Compared to the husband's intonation which seems to stay leveled throughout the argument, the mother's tone keeps on rising and rising and rising before she ended the dispute with shouting, "No!" and returning to her son while seeming fine with a smile on her face. This depiction is in line with one of the symptoms of hysteria. According to Freud, hysteria refers to an umbrella term for a wide array of mental illnesses that include hallucination, exaggerated emotional responses, and even psychosomatic symptoms disadvantaging the sufferer. Freud and Breuer (2009) stated that hysteria is caused not by physiological problems, but rather by mental problems, which means that the cure for it is also psychological in nature. It is also commonly found in women, and its symptoms differ from one person to another (p. 1).

In the game, the mother's hysteria stems from fear of letting her child go so that he could grow up and establish relationships with new people aside from her, including the baby's father represented as the talking teddy bear which she took away at the end of the warehouse stage. In other words, the mother's possessiveness for the baby is what leads up to her castrating the baby by instilling fear in the infant to limit his psychosexual development so that he can merely receive gratifications coming from her.

In the game's dream world, the overall atmosphere is dark, especially when contrasted with the childlike elements such as the playhouse, playground, and castle. Out of the five dream worlds, four are inhibited by a feminine monster lurking around to find the baby. During the second dream world, the monster is only seen walking at a straight trajectory without looking at the player. In the next stage, the monster eventually makes its way closer to the baby, starting from sometimes staring at the baby from the player's point of view in certain distance, up to the point the player can see her face in close-up shot. This finding is the representation of the mother's hysteria in the form of abjection, especially when combined with the change in the mother's portrayal as a human (figure 4 ), then turning into a monster (figure 5) in one of the dreams. 
This is also in line with Kristeva's (1982) theory of abjection as quoted by (Creed, 2007), in which feminine monsters are usually related to something that 'does not respect borders, positions, rules' and 'disturbs identity, system, order', as well as bordering between 'humane' and 'inhumane' to provoke disgust or fear in the audience (p. 4). In the dream, the mother as a monster is depicted similar to a boogeyman with an unnaturally tall and skinny body, pitch black skin, shriveled hair, hairy feet, and a pair of flashing empty eyes. Her movements are also staggered akin to someone under the intoxication of alcohol, and she is always accompanied with an inhumane-sounding growl or screech. Also, the camera is always distorted whenever the baby encounters the monster, which represents his fear shown through crying, therefore blurring his vision.

Compare this with how he approaches the mother in real life during the prelude or her hazy silhouette form in the memories he must collect. The baby would always seek to come close to the mother in the real world. When a memory has been found, the screen's color turns into grayscale to truly contrast the bright white silhouette of his mother, which symbolizes his view of the mother as his 'light' and 'love'. After approaching the silhouette, he is then engulfed in a warm white light.

According to Kristeva quoted by Creed (2007), 'abject' of mother figure lies in the clash between the mother and child caused by the mother's possessiveness against the child trying to 'break free' (p. 11). Abject in mothers is still needed to ensure that the child development goes

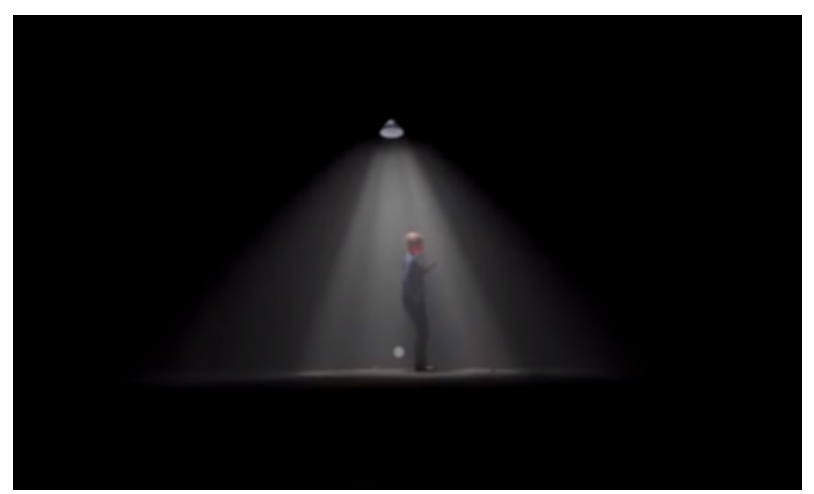

Figure 4. The mother swaying drunk.

(Source: author's personal screenshot of the game. Time taken: July $12^{\text {th }}, 2018$ ) smoothly without any mistakes from the child by showing that she is still more superior in a way, but not to the extent it castrates or cripples the child's development (Kristeva, 1982, p.3). This is also noted by Teddy, who in specific moments pityingly comments, "No child deserves to experience such thing" meaning that he himself does not want the child to experience fear of the mother's abjection. From this example alone, it can be deducted that the game views abjection in a different light from Kristeva. Unlike Kristeva (1982) who views that abject remains a necessary element in child-rearing, the game sees abjection as something that should never exist in the first place when it comes to child-rearing since it can only impact the child's development negatively.

The ending scene also shows the contrast between the mother and the baby's fate. The mother is still trapped in her own hysteria and possessiveness, whereas the baby has let go of his attachment to his mother. There, the baby is shown to have woken up from his dream early in the morning. His toys are missing from his room. He gets out from his dropped crib and traverses through the house, which is now filled with labeled cardboards. Downstairs, in the dimly-lit kitchen, he finds the mother hunched over a counter, sobbing between an empty bottle of alcoholic drink and the teddy bear, whose right arm is missing as a result of the mother (as a monster) ripping it while trying to snatch him away from the baby at the end of the warehouse dream world (see figure 6). If the baby proceeds to approach her, she will scream, "Stay away from me!" and shove the baby away from her with force. At this moment, the baby's

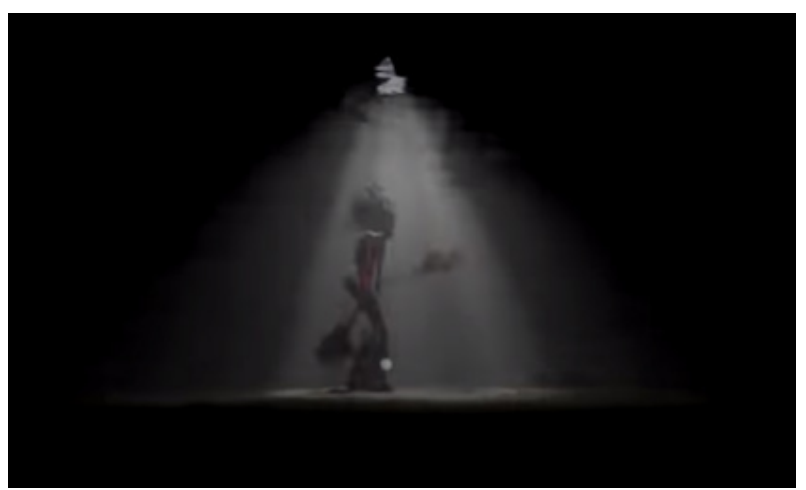

Figure 5. The mother turning into a monster, with the camera distorted. (Source: author's personal screenshot of the game. Time taken: July $12^{\text {th }}, 2018$ ) 
vision becomes blurred and distorted in the same manner as every time he encounters the monster in the previous dreams. After that, the mother gasps and pauses for a while before saying, "I'm sorry... I didn't mean to" while crying.

There is an option for the baby to soothe the mother by pressing a button after approaching her once again, but the game only progresses if the baby heads for the exit. After opening the door, the screen is engulfed with bright light and a voice resembling the talking teddy bear in the dream worlds saying, "Hello there, little one" can be heard. The game finally ends with the baby replying, "Da-da" which shows that the teddy bear is indeed the baby's father figure. From this point onward, there is a possibility that either the father has fully won the rights to child custody or gotten the rights to finally see his son once again. The ending represents the baby finally letting go of his first love and attachment to his mother so that his psychosexual desires and interpersonal skills develop healthily (Freud, 1922).

Additionally, (Stern, 1991) stated that babies will eventually learn to distinguish their mother, father, and other people unrelated to his family (p. 26), so the baby's process of ending his primary attachment to the mother is natural and therefore should be encouraged to develop the needed social skills. Note that the baby's tone while greeting his father sounded cheerful, which means that he has let go of his attachment towards the mother voluntarily. This is different from how the mother ends up at the end of the game.

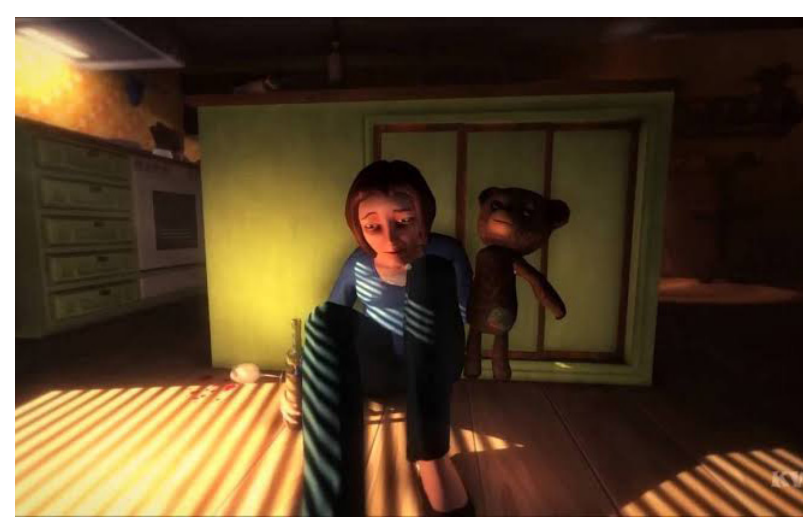

Figure 6 . The mother sitting down and crying with a bottle of alcohol and the teddy bear she has taken away, symbolizing her trapped in her hysteria.

(Source: the author's screenshot of the game. Time taken: July $12^{\text {th }}, 2018$ )
The fact that she attempted to reinforce her son's attachment to her by severing his relationship with the father represented as the teddy bear established her power to dominate over her son in the dream world. However, in the real world of the game, her act proved to be futile as she was shown only to have taken the teddy bear while the baby is still reunited with his father. Therefore, unlike the baby, she is pictured to be powerless over her hysteria and her desire to keep her son all to herself.

After learning what the monster truly symbolizes inside the baby's dream through its action in the last stage and near the ending taking place inside the real world, the story has come to a full circle all while leaving the player shaken by the revelation. On the other hand, it is also ironic to see the stark contrast between the mother in the real life and in the dream world as a monster. In the dream world, the baby views the mother as a highly threatening monster trying to prevent him from exiting the dream world and reuniting with his real mother, but in real world, she can only use alcoholism as her mechanism to cope with the fact that her son no longer needs her to fulfill his needs because he has broken free from her abjection.

This causes the relief felt by the player even more when they hear the father greeting him in such a tone that is similarly soothing as the mother before finding out what she really is in his dreams, and the baby finally greeting him back happily as he leaves the kitchen where the mother is slumped through the back door. It is a moment that can be translated into how the scary boogeymanresembling monster of the mother's abject trait is no longer a castrating threat to the baby's psychological and developmental wellbeing.

\section{Conclusion}

The psychoanalysis framework used to analyze the intrinsic elements of the game reveals that the dreams and memories are indeed the infant's wish-fulfillment aspect to satiate his longing for his distant mother. To some extent, this also reinforces the role behind the dream world traversed by the main character to regain his happy memories with his distant mother, which is his fantasy. As shown 
by the stages' background and objects that he can interact with there, they are remnants of his reality combined with his imagination. Additionally, the happy memories he collects from the dream world are his escape from his mother's neglectful and abusive tendencies directed at him that spring from time to time, which further reinforces their role as a form of fantasy to respond to the occurrences in his real life.

The plot shows the development of the baby's attempt to let go of his attachment towards the mother as his first love object and finally succeeding at it as the perfect illusion of his beloved mother in his mind is contradicted by her transforming into the same antagonistic apparition trying to catch him throughout the game. He finally sees his real mother in the same light as the monster of his dreams. There, she is depicted as a hysterical and possessive mother prohibiting her own child from growing up and developing his psychosexual desires healthily so that she could keep him to herself longer.

From Freudian perspective, her action in the game satiates her needs as a woman to have someone to take care of, and to some lengths, her desire to have a penis by seeing her son as an extension to her wish. This results from hysteria and the fact that women can never have a real penis, and thus feel less superior to men, so they need something or someone to compensate for their inferiority. It is also discovered that while the mother has used abjection to put her son on a 'leash' and abjection is sometimes needed to correct the mistakes made by children while they were still developing, this game views abjection is unnecessary to establish a bond between a mother and her child.

The game heavily relies on the gameplay and the whole artistic aspect such as the somber color palette surrounding the dream world in general as contrasted to the game's real world to deliver their story instead of using many spoken or written narrations to explain everything, which is a noteworthy nod at the fact that infants are unable to form a coherent spoken sentence and also a chance to connect with the main character and his mother's emotion at a deeper level. This contradicts general public's criticism of the game's supposedly mean- ingless and confusing juxtaposition of the dream symbols. At the same time, this also strengthens the general public's praise for the thrilling buildup of the game through its story and visuals so that they can appreciate the positive effect of the game's outcome to the main character after everything he has gone through should it happen in real life.

This research's findings suggest that babies are indeed capable of sensing and processing whatever is happening around them, albeit not being able to express their understanding verbally, and their understanding can influence their behavior and personality when growing up. This sheds a light to tackle the widely spread belief that babies cannot understand their surroundings at all. Taking into account the fact that video games remain a popular media among young adults, Among The Sleep's plotmay be able to demonstrate the importance of creating a positive environment for the growth of children in the first place aimed towards such audience segment looking forward to start their own family. Video games often deliver a certain message-in the case of Among The Sleep, the message is that people can always overcome whatever trauma they are going through, which rings true with the developer's motivation of writing story as stated in their interview — and players should avoid taking it literally. Future research can investigate if there is a common pattern among video games with a similar theme or plot to see if they maintain certain values.

\section{Acknowledgements}

We would like to thank educational instructors of University of Indonesia's English study program for their helpful feedbacks during this paper's research and writing process. We also thank our friends and families for providing us with moral support throughout the makings of this paper.

\section{References}

Ainsworth, M. D. S. (1979). Infant-Mother Attachment. American Psychological Association, 10(34), 932-937.

Creed, B. (2007). The monstrous feminine. New 
York: Routledge.

Freud, S. (1905). Female sexuality (E. Jones, Ed.).

London: The International Psychoanalytical Press.

Freud, S. (1922). Beyond the pleasure principle (E. Jones, Ed.). London: The International Psychoanalytical Press.

Freud, S. (1927). Fetishism (E. Jones, Ed.). London: The International Psychoanalytical Press.

Freud, S. (2010). The interpretation of dreams (8th ed.; J. Strachey, Ed.). Philadelphia: Basic Books.

Freud, S., \& Breuer, J. (2009). Studies on hysteria (J. Strachey, Ed.). Philadelphia: Basic Books.

Kristeva, J. (1982). Powers of horror: An essay on abjection (L. S. Roudiez, Ed.). New York: Routledge.

Lacan, J. (1953). The seminar of Jacques Lacan book
IV (J.-A. Miller \& D. Porter, Eds.). New York: Routledge.

Lichtenberg, J. D. (1998). Psychoanalysis and infant research. New York: Routledge.

Lyons-Ruth, K. Dutra, L. Schuder, M. R. Bianchi, I. (2006). From infant attachment disorganization to adult dissociation: relational adaptations or traumatic experiences? The Psychiatric Clinics of North America, 29(1), 63-86.

Putri, V. A. (2014). Fenomena mimpi dalam tokoh utama Mimpi Bungsu karya Vanny Chrisma W. Universitas Negeri Yogyakarta.

Share, L. (1994). If someone speaks, it gets lighter: Dreams and the reconstruction of infant trauma. New York: Routledge.

Stern, D. N. (1991). The interpersonal world of infant. New York: Routledge. 